\section{International Scientific Journal Theoretical \& Applied Science}

p-ISSN: 2308-4944 (print) $\quad$ e-ISSN: 2409-0085 (online)

Year: $2015 \quad$ Issue: $07 \quad$ Volume: 27

Published: $30.07 .2015 \quad$ http://T-Science.org

SECTION 12. Geology. Anthropology.

Archaeology.
Nargiz Malik Gulieva

doctor of historical sciences, professor, Institute of Archaeology and ethnography Azerbaijan National Academy of Sciences, Baku, Azerbaijan

EInur Latif oglu Hasanov Corresponding member of International Academy of Theoretical and Applied Sciences, Ph.D. postgraduate Institute of Local-lore of Ganja Branch Azerbaijan National Academy of Sciences, Ganja, Azerbaijan 1-hasan@hotmail.com

\title{
ABOUT INNOVATIVE FEATURES OF RESEARCH OF TYPICAL ETHNODEMOGRAPHIC CHARACTERISTICS OF GANJABASAR REGION
}

\author{
Abstract: As you know, Ganja is one of the oldest cities in the Caucasus. In this scientific work have been \\ researched the main features of research of local ethnodemographic features of Ganja and the whole Ganjabasar \\ Key words: Azerbaijan, Ganja, ethnodemography, innovative scientific methods. \\ Language: English \\ Citation: Gulieva NM, Hasanov EL (2015) ABOUT INNOVATIVE FEATURES OF RESEARCH OF \\ TYPICAL ETHNODEMOGRAPHIC CHARACTERISTICS OF GANJABASAR REGION. ISJ Theoretical \& \\ Applied Science 07 (27): 7-11. \\ Soi: http://s-o-i.org/1.1/TAS-07-27-2 Doi: crossef http://dx.doi.org/10.15863/TAS.2015.07.27.2
} region.

\section{Introduction}

Ganja city is the motherland of the great poets and philosophers as Mahsati Ganjavi (XI-XII centuries), Nizami Ganjavi (XII century) and others. Ganjabasar region is an area of Ganja city and around territory. This part of Azerbaijan is one of the main regions. The economic life of modern families in Azerbaijan is diversified and has rich historical roots. Farming, cattle-breeding, hunting, fishing, vegetable-growing, silkworm-breeding and beekeeping and handicrafts have been playing the principal role in the economic life of nation over centuries, while fertile lands, favorable natural conditions and various natural riches created broad opportunities for the development of the said branches of agriculture. It is known that the economic life of families is closely linked to the production of material values. Rural population makes a particular contribution to this. In Azerbaijan, with the area of 86,600 square kilometers, there are 60 towns, 125 suburban settlements, 61 regions and around 4, 300 villages. Large families continued to exist in Azerbaijan, also in Ganjabasar region, which situated in the western part of country till 1930s.

The composition of large families included 3-4generation families with the joint living of several brothers on the basis of agnate kindred relations. All members of families of such sort lived together and worked for a single economy. Head of the family was the family's man, "ata" (the father), after whose death the leading role in the family went over to his elder son. Other men of a family were subordinated by him. He also settled matters related to the properties of his family. Particular position and role in such family belonged to "beyuk ana", "agbirchek" (the elder mother). She controlled performance of homework [1].

\section{Materials and methods}

The article's objective is to eliminate this gap, analyze changes in family life of rural population in Ganjabasar region since then, directions of development, important features of rites and peculiarities, and study modern family life-related processes in rural locations on the basis of materials obtained in rural parts of this region.

For this purpose, there were settled the following tasks:

- On the basis of statistical and field ethnographic materials, there were specified, more accurately than before, principal and regional peculiarities of modern family life of the population of rural parts of Ganjabasar region

There were identified typical peculiarities of family life of modern population of Ganjabasar; 
- There were studied the type, structure, numerical composition and inter-family relations of a modern rural family;

- Ethnographically, there were studied functions of a family and the system of kindred relations;

- There were studied changes and local peculiarities of spiritual life of families;

- There were studied traditional and new peculiarities of a marriage, a wedding, the upbringing of children in family, and funeral rites;

- There were identified customs similar to that of other nations, including new customs, rites and habits in modern family life.

Certainly, large families existed historically and had had deep roots and definite frames in Ganjabasar, also in a whole Azerbaijan prior to the first quarter of the $20^{\text {th }}$ century; more exactly, they comprised a large family, inside which several smaller families who had concluded marriage contract, and their children, parents and so on lived. So, the existence of monogamy in large families, under the father's full domination, did not mean yet establishment of an economically independent monogamous family in the conditions of those times. Development of production force had not yet reached a level, under which a separate small family consisting of a husband and a wife could manage the family economy independently. At a time when labor productivity was insufficient to meet demands of members of the community in full, the only economic unit could be a patriarchal family consisting of representatives of 4 to 5 generations only on the father's side, and their wives and children. All members of families were subordinate to the father only [3]. In researchers' opinion, large families give continuation to human life, e.g. such families usually consist of three or, for rare exception, four generations under the condition that the number of descendants increases within the entire family. The head of a large family settled all relations within the family $[2 ; 3]$. The economic function of a large family was based upon instruments of labor and production of goods that it privately owned. The main regulator of a large family was its head: man-father.

Large families, with all features mentioned above, are subdivided into the following several kinds: a branchy patriarchal family, a branchy fraternal family, and one-sided integrated family of relatives. From historical point, patriarchal families are most ancient of them all. There were a lot of survivals in the way of life of a patriarchal family in Azerbaijan at the end of the $19^{\text {th }}$ century, in the beginning of the $20^{\text {th }}$ century and even in early years of the Soviet power. In families of such kind, orphan children were brought up under care of uncle-the brother of the father or the mother. Properties inside the family were distributed in accordance with the
Islamic law. The share of boys was bigger than that of girls. The family head gave the widow woman $1 / 8$ of the dowry that she had brought in accordance with the terms of marriage contract [3-7]. In the ethnography, establishment of the form of a large patriarchal family is related to the formation of private property and transition, as a result of decision by the father's kin, to a primitive rural commune. This means that a tribe with the blood relationship was substituted by a patriarchal family. It goes without saying that such a family was an economic cell; its members jointly produced goods and used everything together [1].

\section{Conclusion and Recommendations}

Property of a family was the indivisible property of all its members. The development of capitalist relations in villages in Ganjabasar, also in a territory of Azerbaijan, the conduct of agrarian reforms and, finally, the politics of collectivization caused division of large families and, as a consequence, establishment of patronymic clans. In modern villages, such patronymic names as kok, ushagy, nasil, evlari, tirya, nasil odjagy, tayora, toryamya, agroba, etc. mean kindred relations while myahlya, tyaryaf, shenlik, oba, etc. mean neighborhood relations. Demographic processes also influence upon the composition of families. The number of Azerbaijan's population was equivalent to 2,861,000 in $1917,2,314,000$ in $1926,3,205,000$ in 1939 , $3,698,000$ in $1959,5,117,000$ in $1970,6,028,000$ in 1979 , and 7,038,000 in 1989. Rural population plays particular role in the creation of material values in Azerbaijan. The share of rural population in total number of Azerbaijan's population was $76 \%$ in 1913 , $76.8 \%$ in $1917,71 \%$ in $1926,64 \%$ in $1939,52 \%$ in $1959,50 \%$ in $1970,57 \%$ in 1979 , and $47 \%$ in 1989 . Common indications of family relations and structure of Ganja city and Ganjabasar's families resemble the structure of families of other nations of the world. However, a series of local specific peculiarities as well as peculiarities of national rites and customs distinguish Azerbaijani families from other. Establishment of appropriate conditions for economic independence in agricultural regions provides the independent life of members of agricultural families.

Availability of every family's opportunities for construction of living houses for young families at a personal or supplementary plot brings to an increase of the number of nuclear families and, as a consequence, the number of small families increases. Heading families of such sort is primarily the father, i.e. the house's man. The specific features of nuclear families are displayed through interrelations, norms of behavior and respect for the elders in a family. The composition of generations in modern families includes those having one marriage contract (individually incomplete, simple families), those who 
have not married, mothers and children, widowers, widows and divorced persons. The complex family includes those having two or more marriage contracts (the complete family), marriages concluded by widowers or widows (the incomplete family) as well as families with several marriage contracts. The number of small families, which are typical for Azerbaijan, is $58.7 \%$ and $65.1 \%$ in urban localities and rural localities, respectively, of total number of families. According to the minority custom, the younger son remains to live in the father's house. Other children living outside the family continue to keep relations with the parents no matter whether they live. Examination and exploration of familyrelated modern issues illustrate that the structure of families and direction of family relations are displayed in various spheres of family life, such as social and professional composition of and the number of rural families; incomes, expenditures, living conditions, and regulation of material and spiritual life of rural families. A specific feature of families is reflected in the issues of democratization, inter-family relations, economic works, reproduction, upbringing of children, etc. Playing a principal role in a family is proportionate division of labor, legal equality of men and women, the conclusion of a marriage in conformity with the state laws, and the conduct of the wedding ritual. National customs are getting updated, developed and sophisticated. As is known, the number of families in Azerbaijan was 32,789 in $1925,770,900$ in $1959,956,700$ in 1970 , $1,102,700$ in 1979 and $1,381,400$ in 1989 . Noteworthy is that most developed rural families comprise specialists and persons of different social and professional composition. Therefore, public and economic changes in the community influence upon families as well. Birth, upbringing, economic, material-economic and other functions are specific peculiarities of rural families. Kindred relations regulate the Azerbaijani system of kinship and itdescribing terms. Marriage and family rituals and customs are getting renovated and updated, with their local specific peculiarities preserved. In the studied period, monogamous marriages were the main form of marriage in Azerbaijan. The number of such marriage forms as levirate, sororate, "beshikkyartmya", and "bash-basha" was quite insignificant while the number of marriages between cousins was essential. The number of girls who have not married increases because the outflow of the youth from villages has increase due to economic and spiritual discrepancy. Apart from traditional customs, there were developed new customs related to the wedding ritual. However, some traditional customs, for instance, "bashlyk" have been preserved in certain regions in a modified form. Currently, folk holidays of families are celebrated at state level. In the Soviet era, religious holidays were celebrated voluntarily, not at state level. For this reason, rituals related to such holidays were observed inside families. In addition, families started celebrating calendar and professional holidays. It is known that development of education contributes to an increase of the education level of members of families; education, economic activity, and family relations play definite role in the cultural life of rural families. Naturally, all public achievements in the sphere of moral progress, and development and formation of a personality find their reflection in a family.

It should be noted that the Soviet rule had existed in Azerbaijan in 1922-1991; the economy of Azerbaijan had been developing under the Soviets for 70 years; the cultural level of the population had increased as well. Hence, on the eve of the breakdown of the USSR, in Azerbaijan, due to the accumulated economic, scientific-technical and cultural potential, there was created the basis for an independent existence of the Republic. The Communist Party of Azerbaijan was liquidated in the course of its $23^{\text {rd }}$, extraordinary congress on September 14, 1991. Azerbaijan regained its independence on October 18, 1991. Since then, the independent Azerbaijani state has gained successes in the field of independent domestic and foreign policy. The number of Azerbaijan's population in those years was $8,141,400$, including $50.8 \%$ and $49.2 \%$ as urban population and rural population, respectively, and 3,988,300 (49.9\%) as men and $4,152,600(51 \%)$ as women. Development of marketoriented economy influenced upon a family as well. In Azerbaijan, there were formed bases of new political and socioeconomic relations: an Azerbaijani family started being formed in accordance with these bases. All processes in the community historically penetrated family life. In this regard, the period of 1990s occupies a considerable place. It is known that the $20^{\text {th }}$ century was contradictory, diverse for the Azerbaijani nation. For example, in 1920, 19,000 square kilometers of Azerbaijan's land were seceded from Azerbaijan and passed to Armenia. World War I, the foreign military intervention, the civil war, discords between the Armenians and the Azerbaijanis and, as a result, the genocide of Azerbaijanis and the repressions of the 1930s had led to a decrease of the number of Azerbaijan's population by 387,000 - from $2,339,200$ to 1,952,200 (16.6\%); in the years of the Great Patriotic War, the number of Azerbaijan's population had decreased by $17.4 \%$ : from $3,274,000$ in 1940 to $2,705,600$ in 1945; as a consequence, the number of population had got restored only in 1955. Contributing, to a certain extent, to this were the 150,000 Azerbaijanis who had been expelled from Armenia in 1948-1953. Starting from 1988, the undeclared aggressive war of Armenia against our nation and country has caused a significant deterioration of family-life relations in Azerbaijan. In 1988-1989, on the eve of disintegration of the USSR, 
230,000 Azerbaijanis-residents of Armenia were expelled from that country. More than 50,000 Mesheti Turks - refugees from Central Asia and Kazakhstan - arrived in Azerbaijan in 1990.

In 1992-1993, the Armenians occupied Azerbaijan's 7 regions bordering Nagorno Karabakh. Thus, with the number of Azerbaijanis ousted from Armenia in consideration, more than 1 million Azerbaijanis have become refugees and internally displaced persons in their native country. Noteworthy is that 20,000 people were killed and the same number of people were injured, 8,434 people became invalids, and more than 5,000 were taken prisoners, hostages or missed. In 1990-1994, Armenian armed forces occupied a total of Azerbaijan's 14 regions and 834 villages with the total area of 17,300 square kilometers, i.e. $20 \%$ of the territory of the Azerbaijan Republic. Around 700,000 Azerbaijanis were forced to live places of their residence in Nagorno Karabakh and adjacent areas. As a result of the occupation, Azerbaijan suffered damaged estimated at $\$ 60$ billion. Note that 188,540 families became homeless and lost their properties; of internally displaced persons, $54.15 \%$ and $45.85 \%$ live in urban localities and rural localities, respectively. According to the 2000 statistical data by the State Commission of the State Committee for refugees and internally displaced persons, "in the occupied territories of the Azerbaijan Republic, there were destructed around 6,000 agricultural and industrial facilities, 102,000 living houses, 4,366 social-cultural objects, 7,000 public buildings, 693 secondary schools, 855 preschool institutions, 695 hospitals and other medical institutions, 10 mosques, 1 bridge, 368 clubs, 927 libraries, 85 school museums, 464 museums and historical monuments, 6 state theaters, 800 kilometers of railways and motorways, 15,000 kilometers of electric and gas mains, and 2,300 kilometers of water pipelines of regional importance". In the occupied areas, the Armenian separatists took over 31 mosques, 9 historical palaces, 1 million hectares of agricultural lands, 250,000 hectares of forests, and 200 Paleontological, regional monuments [2-7]. In Azerbaijan, 4,514 families were killed for their fight for motherland, and there are 4,395 orphan children, 41 national heroes, and 988 freed hostages. "The State Reward over solution of the problem of refugees and internally displaced persons" established in accordance with Decree \#895 of the President of the Azerbaijan Republic on September 17, 1998 was designated to defend the rights of refugees and internally displaced persons, and conduct consequent measures over their accommodation, rehabilitation, repatriation, social security, etc. In Azerbaijan, there are 72,951 veterans of the Karabakh war. The families of invalids and those killed at war every year are supplied with modern living residences and cars by the Ministry. Solution of social problems in
Azerbaijan is under permanent control of the state, which increases care of people with low incomes from year to year. Expenditures related to social security are provided annually from state budget. The state builds private houses for refugees and internally displaced persons and improves their living conditions. The level of education of Azerbaijan's population has increased considerably over the years of independence. In 2000, the literacy rate of population over 15 was $98.8 \%$. In the years of independence, there have been significant achievements in industries, construction, transport, trade, economy and services. Indeed, around 50 million Azerbaijanis live around the globe. Of them, 9 million live in Azerbaijan; 30 million live in Iran while the rest live in Turkey, Russia, Germany, Iraq, Saudi Arabia, the UK, Indonesia, Georgia, Kazakhstan, Uzbekistan, France, Japan and other countries [2]. In 1999, the number of households in Ganjabasar was 382,499, but in a whole Azerbaijan was $1,687,582$. The number of population of these households was 7,953,438. The number of households with 1 member was 130,589, 2 members138,709, 3 members-213,644, 4 members-350,136, 5 members-348,327, 6 members-230,931, 7 members$111,113,8$ members-65,567, 9 members-38,150, and 10 or more members- 62,416 , with the number of the latter's members of 741,057 . Of households, $46 \%$ and $54 \%$ lived in rural places and urban places, respectively, the number of their members was $49 \%$ in rural places and $51 \%$ in urban places. Fourmember families prevailed in urban places while 5member families prevailed in rural places.

Marriage provided a considerable impact on birth rate in Azerbaijan in 1999. In those years, the annual number of marriages and divorces was around 57,000 and 8,000 , respectively. The number of woman in fertile age was 2,311,000. In the beginning of 2009 , there were $1,887,800$ families in the Azerbaijan Republic, including 1,083,600 in urban places and 804,200 in rural places. The number of one-member families was 109,000 in towns and 37,100 in villages [3]. The number of members of a family averaged 4.7 , with the figure equivalent to 4.4 in towns and 5.1 in villages. As of early 2009, there lived 4,358,300 men (49\%) and $4,338,600$ women $(51 \%)$ in Azerbaijan. The number of women in fertile age was $2,694,929$ or $59.4 \%$ of total number of female population. In 2008, the number of births and deaths in Azerbaijan was 12,086 and 52,710, respectively. The natural increase was 99,376. In 2008, in Azerbaijan, there were registered 79,964 marriages and 7,933 divorces. As of early 2009, operational in Azerbaijan were 752 hospitals, 1,695 ambulatory-polyclinic institutions, and 912 antenatal clinics and children's polyclinics. Working for these institutions were 32,500 physicians and 62,500 nurses [2]. In 2008, the number of economically active population was 
$4,318,200$. Of them, the number of employed persons was $4,056,000$ (93.9\% of total) and the number of unemployed persons was 262,200.

The number of those receiving the unemployment grant was 2,109, including 1,350 men and 758 women. Total incomes of population reached to 4,047.3 million manats and 20,058.2 million manats in 2000 and 2008, respectively, while the expenditures of population in the said years were 3,272.2 million manats and 15,309.8 million manats, respectively. In 2009, 163,409 families received the purposeful state social aid [1]. Specialists and persons of different social and professional composition live in modern families. Therefore, socioeconomic changes in the community influence upon families as well. Occupying a significant position in the economic life are the financial provision of every member of a family, common needs of family members, homework, economic works, division of labor among family members, etc. The economic function of family lays down its material ground. Family budget is provided at the expense of earnings of its members, various state grants, and incomes obtained from personal plots. Women play a particular role in all spheres of domestic family life and sociopolitical life in Azerbaijan. They work equally with men in all fields of economy, science, culture and public life. The availability of developed economic, scientifictechnical and cultural potential in Azerbaijan has established grounds for the existence of Azerbaijan as a fully independent state. Indeed, Azerbaijan lives as an independent state today. In the future it is necessary to continue the main ethnodemographic researches about Ganja and Ganjabasar region.

\section{References:}

1. (2009) Azərbaycanda qadınlar və kişilər Bakı, $62 \mathrm{p}$.

2. Guliyeva NM (2011) Family and family life in modern Azerbaijani village. Baku: Elm, 190 p.

3. Guliyeva NM, Hasanov EL (2012) Encroachment of Armenia upon Azerbaijan and its influence to family and social relations of the Azerbaijanis, lived in Armenia. Proceedings of the 4th International Congress of Eurasian Archaeology, Agsu. pp. 207-209.

4. Guliyeva NM, Häsänov EL (2014) Die traditionelle Gändschänischen Teppiche von Zeitraum der Aserbaidschanischen Gelehrten und Dichter Mirsä Schäfi Waseh als ethnoanthropologische quelle (XIX Jahrhundert). European Applied Sciences, 2: pp. 3-5.

5. Gasanov EL (2014) Traditsionnye etnoantropologicheskie i istoricheskie osobennosti osnovnykh remeslennykh otrasley Gyandzhi XIX - nachala XX v. Vestnik Leningradskogo gosudarstvennogo universiteta im. A.S. Pushkina. T. 4. № 3. pp. 86-90.
6. Gasanov EL (2014) O razvitii traditsionnykh remeslennykh otrasley Gyandzhi na rubezhe XIX-XX vekov. Fundamental'nye issledovaniya. № 9-4. pp. 892-895.

7. Hasanov EL (2014) To the question on the research of typical features of craftsmanship heritage of Ganja of the late XIX - early XX centuries. ISJ Theoretical \& Applied Science 12(20): 27-30. doi: http://dx.doi.org/10.15863/TAS.2014.12.20.7

8. Hasanov EL (2015) Multidisciplinary approach to investigation of the basic handicraft branches of Ganja till the XX century. ISJ Theoretical \& Applied Science 1(21): 7-15. DOI: http://dx.doi.org/10.15863/TAS.2015.01.21.2

9. Həvilov HA (1991) Azərbaycan etnoqrafiyas1. Bakı: Elm.

10. Smith WB, Hasanov EL (2013) Importance of handicraft traditions in investigation of history of urban culture in Ganja. ISJ Theoretical \& Applied Science 11(7): 61-66. doi: http://dx.doi.org/10.15863/TAS.2013.11.7.10

11. Tərlanov M, Ofəndiyev R (1960) Azərbaycan xalq sənəti. Bakı: Uşaq gənc nəşr. 